\title{
Absence of Mycoplasma spp. in nightingales (Luscinia megarhynchos) and blue (Cyanistes caeruleus) and great tits (Parus major) in Germany and its potential implication for evolutionary studies in birds
}

\author{
Luisa Fischer ${ }^{1,2}$ - Franca Möller Palau-Ribes ${ }^{1} \cdot$ Silke Kipper $^{3,4} \cdot$ Michael Weiss $^{3,5} \cdot$ Conny Landgraf $^{3,6} \cdot$ Michael Lierz $^{1}$
}

Received: 15 January 2021 / Revised: 28 June 2021 / Accepted: 24 November 2021 / Published online: 6 December 2021

(c) The Author(s) 2021

\begin{abstract}
Mycoplasma spp. are important pathogens in poultry and cause high economic losses for poultry industry worldwide. In other bird species (e.g. white storks, birds of prey, and several waterfowl species), Mycoplasma spp. are regularly found in healthy individuals, hence, considered apathogenic or part of the microbiota of the upper respiratory tract. However, as Mycoplasma spp. are absent in healthy individuals of some wild bird species, they might play a role as respiratory pathogen in these bird species, e.g. Mycoplasma gallisepticum in house finches. The knowledge on the occurrence of Mycoplasma spp. in wild birds is limited. To evaluate the relevance of Mycoplasma spp. in free-ranging nightingales and tits, 172 wild caught birds were screened for the presence of mycoplasmas. The birds were sampled via choanal swabs and examined via molecular methods $(n=172)$ and, when possible, via culture $(n=142)$. The Mycoplasma sp. was determined by sequencing the 16S rRNA gene and 16S-23S Intergenic Transcribed Spacer Region. All birds were tested negative for mycoplasmas via PCR and/or mycoplasmal culture. Hence, free-ranging nightingales and tits do not show any mycoplasma in their microbial flora of the respiratory tract. Therefore, these songbird species may suffer from clinical mycoplasmosis when being infected. We hypothesize that birds relying on their vocal ability for reproduction have excluded mycoplasmas from their respiratory flora compared to other bird species.
\end{abstract}

Keywords Apathogenic mycoplasmas $\cdot$ Cyanistes caeruleus $\cdot$ Luscinia megarhynchos $\cdot$ Parus major $\cdot$ Songbirds $\cdot$ Song voice

In domestic poultry Mycoplasma gallisepticum, Mycoplasma synoviae, Mycoplasma meleagridis, and Mycoplasma iowae are the most relevant pathogens, causing high economic

Luisa Fischer

Luisa.Fischer@lanuv.nrw.de

Franca Möller Palau-Ribes

Franca.Moeller@vetmed.uni-giessen.de

Silke Kipper

silkip@zedat.fu-berlin.de

Michael Weiss

miweiss@zedat.fu-berlin.de

Conny Landgraf

landgraf@izw-berlin.de

Michael Lierz

Michael.Lierz@vetmed.uni-giessen.de

1 Clinic for Birds, Reptiles, Amphibians and Fish, Justus

Liebig University Giessen, Giessen, Germany losses. Furthermore, Nolan et al. (1998) estimated that 100 million House Finches (Carpodacus mexicanus) died in an outbreak of disease caused by Mycoplasma gallisepticum in

2 Wildlife Research Institute, State Agency for Nature, Environment and Consumer Protection North Rhine-Westphalia, Bonn, Germany

3 Animal Behaviour Group, Free University of Berlin, Berlin, Germany

4 Chair of Zoology, School of Life Sciences Weihenstephan, Technical University Munich, Munich, Germany

5 Unit Plant Toxins and Mycotoxins, Federal Institute for Risk Assessment (BfR), Berlin, Germany

6 Leibniz Institute for Zoo and Wildlife Research (IZW), Berlin, Germany 
the US because of severe conjunctivitis and consequential loss of eyesight. Several other passerine species have been affected by Mycoplasma gallisepticum infections (Mikaelian et al. 2001) too. However, in certain avian species, mycoplasmas are known as apathogenic bacteria of the respiratory tract showing a commensal character. For example, commonly isolated Mycoplasma spp. in Galliformes include Mycoplasma gallinarum (Poveda et al. 1990) and Mycoplasma gallinaceum (Jordan et al. 1982). In healthy birds of prey, Mycoplasma buteonis, Mycoplasma falconis, and Mycoplasma gypis were isolated from up to $100 \%$ of the sampled freeranging birds (Lierz et al. 2008). Mycoplasma ciconiae was descripted as a commensal Mycoplasma sp. as it was detected in $99.1 \%$ of healthy, free-ranging white storks (Ciconia ciconia) (Möller Palau-Ribes et al. 2016). In studies on clinically healthy, free-ranging pelicans (Pelecanus onocrotalus) $98 \%$ were tested positive for mycoplasmas, however, there was no species differentiation performed (Assunçã̃o et al. 2007). In contrast, no mycoplasmas were found in healthy individuals belonging to other bird species e.g., psittacines or passerines (Lierz and Hafez 2009; Deem et al. 2012). In corvids, mycoplasmas were isolated from diseased birds (Pennycott et al. 2005), but also from $7 \%$ of clinically healthy individuals (Ziegler et al. 2017). Therefore, corvids seem to occupy an intermediate position, so that mycoplasmas may play a role in respiratory disease.

These findings lead to the hypothesis that species using sexually selected song traits as mating signals such as many passerines have a lower tolerance towards mycoplasmal infections of the respiratory tract, as respiratory disease would imply disadvantages in their mating behavior. Though not for Mycoplasma gallisepticum, it has been shown for other parasites and pathogens that they may reduce song performance measures and thus have an effect on mating success (Buchanan et al. 1999; Garamszegi et al. 2004; Spencer et al. 2005; Owen-Ashley et al. 2006; Gilman et al. 2007; York et al. 2016). These studies suggest that parasites may have played an important role in the evolution of sexually selected traits (Garamszegi et al. 2004). According to this suggestion, song may serve as an honest indicator of a strong immune system, which in turn might be a mate choice criterion for females to increase offspring fitness. Species not relying predominantly on vocalizations in mate choice decisions likely have not faced the same evolutionary pressure on the maintenance of a well-functioning vocal tract. To prove this thesis and to obtain more information on the occurrence of mycoplasmas in free-ranging, healthy passerine bird species using vocalizations in many communicative contexts and in particular in mating behavior, free-ranging nightingales and blue and great tits were sampled.

Samples were obtained in the context of different projects investigating functions of song during mating (in nightingales) in Golm (near Potsdam) and Berlin-Treptow or effects of supplemental feeding (in tits) in Berlin-Tempelhof. All adult birds were caught randomly and tested at the beginning of the breeding season, when they are territorial and live solitary (or in pairs). Chicks were tested in the nest. All study areas comprised several square kilometers and the majority of birds in these areas were tested, making sampling biases rather unlikely.

Birds were caught using mist nets to ring them and to obtain body measures, data on condition, and physiological samples (Landgraf et al. 2017).

Swabs were obtained from the pharyngeal region due to the small bird size. If birds would have shown any clinical signs of a mycoplasmosis e.g., conjunctivitis, respiratory signs, or arthritis, they would have been excluded from the study. However, this never occurred. Overall, 97 nightingales (Luscinia megarhynchos), 40 great tits (Parus major), and 35 blue tits (Cyanistes caeruleus) were screened for the occurrence of mycoplasmas prior to being ringed. In total, 31 were juvenile and 111 adult birds. In 30 cases, the bird's age was not documented. DNA extraction of all swabs was performed as described by Ziegler et al. (2017). All samples $(n=172)$ were screened via Mycoplasma genus-specific PCR (target sequence: 16S rRNA gene) as described by van Kuppeveld et al. (1992) modified by Lierz et al. (2007). One hundred forty-two samples were additionally cultured using SP4 liquid and agar media as described by Bradbury (1998) to isolate mycoplasmas.

Within this study, all birds were tested negative for mycoplasmas via Mycoplasma genus-specific PCR. Furthermore, it was not possible to isolate any mycoplasmas via culture.

The results of the present study indicate that the investigated populations of passerine species (nightingales, great and blue tits) do not show any mycoplasmas as part of their physiological respiratory flora. However, prior studies indicated that some songbirds do show detectable mycoplasmas in their respiratory tract, as there were $7 \%$ of healthy free-ranging corvids tested positive for Mycoplasma sturni (Ziegler et al. 2017). As all birds under study were tested negative for mycoplasmas and the prevalence of Mycoplasma spp. in corvids was rather low, it seems plausible to suggest that most bird species of the order Passeriformes may not have mycoplasmas in their physiological microbial flora of the respiratory tract. Especially the lack of mycoplasmas in several highly vocal passerine species (e.g., nightingales, blue and great tits) in which song is an important signal to demonstrate male quality to females (Bartsch et al. 2015; Poesel et al. 2001; Rivera-Gutierrez et al. 2010; Weiss et al. 2012), back the hypothesis that these species may not tolerate latent infections of the respiratory tract. This theory may be supported by the fact that healthy psittacines, also highly vocalizing, did not show mycoplasmas in their respiratory tract as well (Lierz and Hafez 2009). This is additionally underlined 
by the presence of mycoplasmas in the respiratory tract of healthy birds of prey and white storks (Lierz et al. 2008; Möller Palau-Ribes et al. 2016) which do not rely predominantly on vocalizations in communication in general and in the mating context in particular. In passerines living closely to poultry flocks, poultry pathogenic mycoplasmas can occasionally be found in the upper respiratory tract (Hussein 2016; Stallknecht et al. 1982). However, as seen in the last decades, a single successful host jump of Mycoplasma gallisepticum can lead to an epidemic of mycoplasma-induced conjunctivitis in passerine birds, in this case in House finches (Haemorhous mexicanus) in the United States (Hochachka et al. 2013). Therefore, we speculate that one predisposing factor for a bird species to develop severe symptoms after an infection may be the lack of commensal mycoplasmas in the respiratory tract. Thus, every mycoplasma-host-combination needs careful evaluation to assess its significance. While case reports on mycoplasmas from single or low numbers of diseased birds give important insights, systematic studies are essential to provide a baseline for the occurrence on Mycoplasma spp. in free-ranging birds and evaluate exposure and host ranges (Dhondt et al. 2014).

In conclusion, literature and results of the present study provide the first hints that in bird species relying on their vocal ability in mate choice, and thus for reproduction, respiratory infections may lead to a strong evolutionary pressure towards the exclusion of pathogens from their respiratory tract. Species using also other signals than vocalizations for display and mating behavior might be able to compensate for such infections and still be able to succeed in partner selection. Mycoplasmas seem to be an ideal pathogen to investigate this hypothesis, as they are commensals in the respiratory tract of many bird species but may also lead to severe clinical signs in others. Certainly, this hypothesis needs to be confirmed by further studies in bird species completely relying on their song voice in mating behavior compared to those using other displays.

Funding Open Access funding enabled and organized by Projekt DEAL.

Availability of data and material Not applicable.

Code availability Not applicable.

\section{Declarations}

Ethical approval Capturing, ringing, and probing were conducted in the framework of research projects on the behavioral ecology of free-ranging birds: communication, mate choice, and breeding- and population ecology in nightingales, Reg. 23-2347-4-2009 (Landesamt für Verbraucherschutz, Landwirtschaft und Flurneuordnung Frankfurt (Oder)); effects of supplementary feeding in great tits and blue tits-an experiment using stable isotopes,' Reg. G 0060/11; and how hormones regulate vocal plasticity: the effects of melatonin and testosterone on song and mating success in nightingales,' Reg. 00078/12 (Landesamt für Gesundheit und Soziales, Berlin).

Consent to participate All authors contributed to data acquisition and writing of the manuscript

Consent for publication All authors read and approved the final version.

Conflict of interest The authors declare no competing interests.

Open Access This article is licensed under a Creative Commons Attribution 4.0 International License, which permits use, sharing, adaptation, distribution and reproduction in any medium or format, as long as you give appropriate credit to the original author(s) and the source, provide a link to the Creative Commons licence, and indicate if changes were made. The images or other third party material in this article are included in the article's Creative Commons licence, unless indicated otherwise in a credit line to the material. If material is not included in the article's Creative Commons licence and your intended use is not permitted by statutory regulation or exceeds the permitted use, you will need to obtain permission directly from the copyright holder. To view a copy of this licence, visit http://creativecommons.org/licenses/by/4.0/.

\section{References}

Assunçãa P, De Ponte MM, De La Fe C, Ramírez AS, Rosales RS, Antunes NT, Poveda C, Poveda JB (2007) Prevalence of pathogens in great white pelicans (Pelecanus onocrotalus) from the Western Cape. South Africa J Appl Anim Res 32(1):29-32

Bartsch C, Hultsch H, Scharff C, Kipper S (2015) What is the whistle all about? A study on whistle songs, related male characteristics, and female song preferences in common nightingales. $\mathrm{J}$ Ornithol 157(1):49-60

Bradbury JM (1998) Recovery of mycoplasmas from birds. In: Miles R, Nicholas RAJ (eds) Methods of Molecular Biology. Humana Press, Totowa, New Jersey, pp 45-51

Buchanan KL, Catchpole CK, Lewis JW, Lodge A (1999) Song as an indicator of parasitism in the sedge warbler. Anim Behav 57(2):307-314

Deem SL, Cruz MB, Higashiguchi JM, Parker PG (2012) Diseases of poultry and endemic birds in Galapagos: implications for the reintroduction of native species. Anim Conserv 15(1):73-82

Dhondt AA, DeCoste JC, Ley DH, Hochachka WM (2014) Diverse wild bird host range of Mycoplasma gallisepticum in eastern North America. PloS ONE 9(7):e103553

Garamszegi LZ, Møller PA, Török J, Michl G, Péczely P, Richard M (2004) Immune challenge mediates vocal communication in a passerine bird: an experiment. Behav Ecol 15(1):148-157

Gilman S, Blumstein DT, Foufopoulos J (2007) The effect of hemosporidian infections on white-crowned sparrow singing behavior. Ethology 113:437-445

Hochachka WM, Dhondt AA, Dobson A, Hawley DM, Ley DH, Lovette IJ (2013) Multiple host transfers, but only one successful lineage in a continent-spanning emergent pathogen. Proc R Soc B 280(1766):1068

Hussein MA (2016) Epidemiological and diagnostic studies on Mycoplasma gallisepticum and Mycoplasma synoviae originating from 
poultry and non-poultry birds. Dissertation, Justus Liebig University Giessen, Germany

Jordan FTW, Ernø H, Cottew GS, Hinz KH, Stipkovits L (1982) Characterization and taxonomic description of five mycoplasma serovars (serotypes) of avian origin and their elevation to species rank and further evaluation of the taxonomic status of Mycoplasma synoviae. Int J Syst Evol Microbiol 32(1):108-115

Landgraf C, Wilhelm K, Wirth J, Weiss M, Kipper S (2017) Affairs happen - to whom? A study on extrapair paternity in common nightingales. Curr Zool 63(4):421-431

Lierz M, Hagen N, Harcourt-Brown N, Hernandez-Divers SJ, Lüschow D, Hafez HM (2007) Prevalence of mycoplasmas in eggs from birds of prey using culture and a genus-specific mycoplasma polymerase chain reaction. Avian Pathol 36(2):145-150

Lierz M, Hagen N, Hernadez-Divers SJ, Hafez HM (2008) Occurrence of mycoplasmas in free-ranging birds of prey in Germany. J Wildl Dis 44(4):845-850

Lierz M, Hafez HM (2009) Mycoplasma species in psittacine birds with respiratory disease. Vet Rec 164:629-630

Mikaelian I, Ley DH, Claveau R, Lemieux M, Bérubé J-P (2001) Mycoplasmosis in evening and pine grosbeaks with conjunctivitis in Quebec. J Wildl Dis 37(4):826-830

Möller Palau-Ribes F, Enderlein D, Hagen N, Herbst W, Hafez HM, Lierz M (2016) Description and prevalence of Mycoplasma ciconiae sp. nov. isolated from white stork nestlings (Ciconia ciconia). Int J Syst Evol Microbiol 66(9):3477-3484

Nolan PM, Hill GE, Stoehr AM (1998) Sex, size, and plumage redness predict house finch survival in an epidemic. Proc R Soc B 265(1400):961-965

Owen-Ashley NT, Turner M, Hahn TP, Wingfield JC (2006) Hormonal, behavioral, and thermoregulatory responses to bacterial lipopolysaccharide in captive and free-living white-crowned sparrows (Zonotrichia leucophrys gambelii). Horm Behav 49(1):15-29
Pennycott TW, Dare CM, Yavari CA, Bradbury JM (2005) Mycoplasma sturni and Mycoplasma gallisepticum in wild birds in Scotland. Vet Rec 156(16):513-515

Poesel A, Foerster K, Kempenaers B (2001) The dawn song of the blue tit Parus caeruleus and its role in sexual selection. Ethol 107(6):521-531

Poveda JB, Carranza J, Miranda A, Garrido A, Hermoso M, Fernandez A, Domenech J (1990) An epizootiological study of avian mycoplasmas in southern Spain. Avian Pathol 19(4):627-633

Rivera-Gutierrez HF, Pinxten R, Eens M (2010) Multiple signals for multiple messages: great tit, Parus major, song signals age and survival. Anim Behav 80(3):451-458

Spencer KA, Buchanan KL, Leitner S, Goldsmith AR, Catchpole CK (2005) Parasites affect song complexity and neural development in a songbird. Proc R Soc B:2722037-2043

Stallknecht DE, Johnson DC, Emory WH, Kleven SH (1982) Wildlife surveillance during a Mycoplasma gallisepticum epornitic in domestic turkeys. Avian Dis 26(4):883-890

Van Kuppeveld FJ, Van der Logt JT, Angulo AF, Van Zoest MJ, Quint WG, Niesters HG, Galama JM, Melchers WJ (1992) Genus-and species-specific identification of mycoplasmas by $16 \mathrm{~S}$ rRNA amplification. Appl Environ Microbiol 58(8):2606-2615

Weiss M., Kiefer S, Kipper, S (2012) Buzzwords' in females ears? The use of buzz songs in the communication of nightingales (Luscinia megarhynchos). PLoS ONE 7(9):e45057

York JE, Radford AN, Groothuis TG, Young AJ (2016) Dominant male song performance reflects current immune state in a cooperatively breeding songbird. Ecol Evol 6:1008-1015

Ziegler L, Möller Palau-Ribes F, Schmidt L, Lierz M (2017) Occurrence and relevance of Mycoplasma sturni in free-ranging corvids in Germany. J Wildl Dis 53(2):228-234

Publisher's Note Springer Nature remains neutral with regard to jurisdictional claims in published maps and institutional affiliations. 